\title{
Penafsiran Muhammad 'Abduh Terhadap Alquran Surat Al-Nisâ' Ayat 3 dan 129 tentang Poligami
}

\author{
U. Abdurrahman
}

\begin{abstract}
Mubammad Abduh's Perspective on Verses 3 and 29 of Surah Al-Nisâ' about Polygamy. Muhammad 'Abduh is a pioneer and the founder of the Tafsir al-Adab alIjtimẩi school, a style of interpretation of the Koran that emphasizes to the beauty of language (literature) as well as to social criticism toward the improvement of society. According to Abduh, the verses 3 and 29 of Surah al-Nisa [4] does allow polygamy but with strict requirements and restrictions i.e being able to deal justly with wives. In addition, polygamy can only be done by a husband in a certain situation, such as in the inability of a wife to conceive or give birth. Beyond that, according to his view, polygamy should not be done or unlawful. In his interpretation, Abduh uses solution method (tabliliy) with a rational approach (bi al-ray) orientating to social demands (al-ijtimầi).
\end{abstract}

Keywords: polygamy, tafsîr bi al-ra'y, Muhammad 'Abduh

\begin{abstract}
Abstrak: Penafsiran Mubammad 'Abdub Terhadap Alquran Surab al-Nisâ' Ayat 3 dan 129 Tentang Poligami. Muhammad 'Abduh adalah pelopor dan pendiri aliran Tafsîr alAdab al-Ijtimẩi, yaitu suatu corak penafsiran Alquran yang menekankan pada keindahan bahasa (sastra) sekaligus mengarahpada kritik sosial dan perbaikan masyarakat berdasarkan kaidah Qur ani. Menurut Abduh, setelah mengutip Alquran surat al-Nisâ’[4] ayat 3, Islam memang membolehkan berpoligami, tetapi dengan persyaratan dan batasan yang ketat antara lain mampu berlaku adil terhadap istri. Poligami hanya mungkin bisa dilakukan oleh seorang suami dalam hal-hal tertentu, misalnya ketidakmampuan seorang istri untuk mengandung atau melahirkan. Di luar itu, menurut beliau poligami tidak boleh atau haram dilakukan. Dalam penafsiran itu Abduh menggunakan metode tahliliy dengan pendekatan bi al-ra'y, sedangkan corak dan orientasi penafsirannya adalah al-ijtimẩi.
\end{abstract}

Kata Kunci: poligami, tafsîr bi al-ra'y, Muhammad 'Abduh

Guru Besar Fakultas Syariah dan Hukum Universitas Islam Negeri Sunan Gunung Djati Bandung Jl. A.H. Nasution No. 105, Cipadung, Cibiru, Kota Bandung, Jawa Barat 40614

E-mail: uabdrurrahman@uinsgd.ac.id 


\section{Pendahuluan}

Muhammad 'Abduh' dipandang sebagai salah seorang pelopor reformasi dalam Islam yang sangat penting. Pemikiran pembaruannya telah meninggalkan pengaruh tidak hanya di tanah airnya, Mesir, dan dunia Arab lainnya di Timur Tengah, tetapi juga hampir di seluruh dunia Islam, termasuk di Indonesia. ${ }^{2}$

Tokoh-tokoh pembaruan Islam yang muncul pada awal abad ke-20 hingga saat ini, seperti Qosim Amin, ${ }^{3}$ Thoha Husain, ${ }^{4}$ Ali Abdurraziq, ${ }^{5}$ Thantawi Jauhari, ${ }^{6}$ Mushthafa al-Maraghi, ${ }^{7}$ dan lain-lain, merupakan murid-

${ }^{1}$ Lahir di Mesir pada tahun 1849 dan wafat tahun 1905.

${ }^{2}$ Harun Nasution, Muhammad Abduh dan Teologi Rasional Mu'tazilah (Jakarta: UI-Press, 1987), 1. Lihat juga O Scharbrodt, "The Salafiyya and Sufism: Muhammad 'Abduh and his Risâlat al-Wâridât (Treatise on Mystical Inspirations)". Bulletin of the School of Oriental and African Studies, 70 (1), (2007): 89-115. J. H. Escovitz, "He was the Muhammad'Abduh of Syria: A Study of Tâhir Al-Jazầirî and His Influence”. International Journal of Middle East Studies, 18 (3), (1986): 293-310. A. N. Amir, A. O. Shuriye, \& A. F. Ismail, Muhammad Abduh's Contributions to Modernity. Asian Journal Of Management Sciences And Education ISSN, (2012). Dietrich Jung, "Islamic Reform and the Global Public Sphere Muhammad Abduh and Islamic Modernity." The Middle East and Globalization Encounters and Horizons. Stephan Stetter (Eds.). New York: Palgrave MacMillan (2012). Khoury, Nabeel A., and Abdo I. Baaklini. "Muhammad'Abduh: An Ideology of Development." The Muslim World 69, no. 1 (1979): 42-52. Panayiotis Jerasimof Vatikiotis, "Muhammad 'Abduh and the Quest for a Muslim Humanism." Arabica (1957): 55-72. M. Makrum, "Teologi Rasional: Telaah atas Pemikiran Kalam Muhammad Abduh." Ulumuna 13, no. 2 (2009): 277-304. Nurlaelah Abbas, "Muhammad Abduh: Konsep Rasionalisme dalam Islam.” Jurnal Dakwah Tabligh 15, no. 1 (2014): h. 51-68.

${ }^{3}$ Terkait pemikiran Qosim Amin bisa dilihat dalam karya Syaiful Bahri, "Kontribusi Pemikiran Qasim Amin dalam Pembaruan Hukum Keluarga Islam." Al-Ahwal: Jurnal Hukum Keluarga Islam 6, no. 1 (2016): h. 15-28.

${ }^{4}$ Terkait pemikiran Thoha Husain bisa dilihat berbagai tulisan di antaranya Wasid Wasid. "Dinamis-Rasionalis dalam Pemikiran Thaha Husain pada Problematika Peradaban Islam dan Barat." Religió: Jurnal Studi Agama-agama 3, no. 2 (2013). Aksin Wijaya, "Kritik Nalar Tafsir Syi'ri." Millah: Jurnal Studi Agama 10, no. 1 (2010): h. 1-24.

5 Terkait pemikiran Ali Abdurraziq bisa dilihat dalam berbagai tulisan di antaranya karya Badarus Syamsi, "Pemikiran Ali Abdurraziq Tentang Hubungan Islam dan Negara." TAJDID: Jurnal Ilmu Ushuluddin 14, no. 2 (2015): h. 325-342. Dea Ayuni, "Analisis Pemikiran Ali Abdur Raziq Tentang Negara dalam Perspektif Islam.” PhD diss., Universitas Islam Negeri” Sultan Maulana Hasanuddin" Banten, 2018. Asep Ramdan Hidayat, "Islam dan Negara Pemikiran Ali Abd. Ar-Raziq." Mimbar: Jurnal Sosial dan Pembangunan 19, no. 2 (2003): 159-168. Agung Prawoto, "Studi Kritis Pemikiran Politik Ali Abdul Raziq." KALIMAH 16, no. 1 (2018): h. 1-22.

${ }^{6}$ Terkait pemikiran Thantawi Jauhari dalam dilihat dalam karya Muhammad Ali Fuadi, "Ayat-ayat Pertanian dalam Al-Qur'an (Studi Analisis Terhadap Penafsiran Thanthawi Jauhari dalam Kitab al-Jawâhir fî Tafsîr al-Qur'an al-Karîm).” PhD diss., UIN Walisongo, 2016. Fajar Islami Human, "Makna Kata Adna dan Khayr dalam Surat al-Baqarah ayat 61 menurut Tantawi Jauhari dan Fakhr al-Din al-Razy." PhD diss., UIN Sunan Ampel Surabaya, 2018.

${ }^{7}$ Terkait pemikiran Mushthafa al-Maraghi bisa dilihat dalam karya Wisnawati Loeis, "Nilai- 
murid dan tokoh-tokoh yang terpengaruh oleh pemikiran pembaruan Islam Muhammad 'Abduh, baik langsung maupun tidak langsung. ${ }^{8}$

Demikian pula munculnya pembaruan pemikiran Islam di Indonesia, tidak lepas dari pengaruh pemikiran pembaruan Islam Muhammad 'Abduh, yang masuk melalui majalah al-'Urwah al-Qutsq $\hat{a}^{9}$ dan majalah al-Manâr ${ }^{10}$ serta pemikiran-pemikirannya yang terkandung dalam Risâlah al-Tawhid dan Tafsir al-Manâr. ${ }^{11}$ Pemikiran pembaruan Islam tersebut kemudian dimunculkan dan dikembangkan oleh tokoh-tokoh dan organisasi-organisasi secara eksplisit maupun secara implisit menyatakan dirinya sebagai pembawa misi pembaruan Islam, seperti Muhammadiyah, al-Irsyad dan lainnya. ${ }^{12}$

Demikian besar pengaruh pemikiran pembaruan Islam Muhammad 'Abduh ini, sehingga selama kurang lebih satu abad dari sepeninggalnya, berbagai aspek pemikiran pembaruannya dan aktivitasnya baik dalam bidang keagamaan, pendidikan, maupun dalam bidang politik, telah menjadi bahan kajian dan penelitian yang menarik baik bagi para sarjana di Timur maupun bagi para orientalis di Barat.

Beberapa aspek pemikiran pembaruan Muhammad 'Abduh yang telah banyak mendapat perhatian para peneliti antara lain, dalam bidang tafsir,

nilai Pendidikan Islam dalam Tafsir Ahmad Musthafa Al-Maraghi: Studi Analisis terhadap AlQur'an Surat Al-Fîl." Turats (Jurnal Pemikiran dan Peradaban Islam) 7, no. 1 (2011): h. 74-87. Yuli Gusmawati, "Makna Kata Ma’ruf dan Padanannya dalam al-Qur'an (Suatu Kajian Terhadap Penafsiran Al-Maraghi).” PhD diss., Universitas Islam Negeri Sultan Syarif Kasim Riau, 2011. Masnur, "Al-Maraghi (Pemikiran Teologinya)." Anida’36, no. 2 (2011): h. 260-270. Imas Rosyanti, "Penggunaan Hadis dalam Tafsir Al-Maraghi." Diroyah: Jurnal Studi Ilmu Hadis 2, no. 2 (2018): h. 137-146. Ismail, Muhamad Fadlly, Nor Hafizi Yusof, and Wan Ruswani Wan Abdullah. "Metodologi dan Pemikiran Syaykh Mustafa Abdul Rahman: Kajian Terhadap Tafsir Al-Quran Al-Hakim Juzu' Satu." Journal of Maalim al-Quran wa al-Sunnah 12, no. 13 (2017): h. 100-118.

${ }^{8}$ Abdul Mazid Abdussalam al-Mustashib, Visi dan Paradigma Tafsir Alquran Kontemporer, trans. oleh M. Maghfur W (Bangil: al-'Izzah, 1997), h. 218-20.

${ }^{9}$ Diterbitkan oleh Jamaluddin al-Afghâni dan Muhammad 'Abduh di Paris tahun 1883-1884.

${ }^{10}$ Diterbitkan oleh Muhammad 'Abduh dan Rasyîd Rida di Cairo, Mesir. Baca terkait dengan majalah al-Manar dalam Jutta E Bluhm. "A Preliminary Statement on the Dialogue Established Between the Reform Magazine al-Manar and the Malayo-Indonesian World." Indonesia Circle, 11, no. 32 (1983): h. 35-42.

${ }^{11}$ Harun Nasution, Muhammad 'Abduh dan Teologi Rasional Mu'tazilah, h. 1.

${ }^{12}$ Kuntowijoyo, Paradigma Islam Interpretasi untuk Aksi (Bandung: Alfabeta, 1991), h. 49. Lihat juga Ahmad Ali Nurdin. "Islam and State: A Study of the Liberal Islamic Network in Indonesia, 1999-2004.” New Zealand Journal of Asian Studies 7, no. 2 (2005): h. 20. 
pemikiran, teologi, dan pendidikan. Dalam bidang tafsir Muhammad 'Abduh dipandang oleh al-Dzahabi sebagai pelopor dan pendiri aliran Tafsîr al-Adab al-Ijtimẩi, ${ }^{13}$ yaitu suatu corak penafsiran Alquran yang penyajiannya menekankan pada keindahan bahasa (sastra), sedangkan uraian pembahasannya lebih diarahkan pada kritik sosial budaya dan perbaikan masyarakat berdasarkan pada hidayah Alquran. ${ }^{14}$

Berbeda dengan al-Dzahabi, Abdussalâm al-Muhtasib memandang Muhammad 'Abduh sebagai pelopor aliran tafsir rasional yang mengkompromikan pemikiran Islam dengan pemikiran Barat dan menafsirkan Alquran dengan ide-ide dan sivilisasi Barat. ${ }^{15}$ J.J.G Jansen justru menilai kehadiran Muhammad 'Abduh sebagai seorang mufassir yang mempelopori agar memahami Alquran berdasarkan Alquran berbicara atas namanya sendiri. ${ }^{16}$ Dalam pengamatan Jansen, sebelum kehadiran Muhammad 'Abduh penafsiran Alquran lebih merupakan suatu masalah akademis. Tafsir-tafsir yang ditulis oleh para ulama hanya bisa dipahami oleh kalangan masyarakat umum. Karena untuk dapat memahaminya memerlukan pengetahuan bahasa Arab yang mendalam, perangkat ilmu-ilmu Alquran yang amat luas, dan energi intelektual yang cukup besar. ${ }^{17}$ Tafsir Alquran lebih banyak dipenuhi oleh pendapat-pendapat para ulama serta polemik antar mazhab, baik dalam masalah 'aqîdah, syarîah, maupun bâthîniyyah (tasawuf). Padahal menurut Muhammad 'Abduh, pada hari akhir nanti Allah tidak akan menanyakan mengenai pendapat para mufassir tentang bagaimana mereka memahami Alquran.

${ }^{13}$ Muhammad Husain al-Dzahabi, al-Tafsîr wa al-Mufasirûn, II (Cairo: Dâr al-Kutub al-Haditsah, 1976), h. 547-549. Lihat juga Ahmad Zuhri Rangkuti, "Studi Analisis Konsep Muhammad `Abduh (1266-1323 H/1849-1905) Tentang Al-Qawwâmah dan Implikasinya Terhadap Kedudukan Perempuan dalam Hukum Islam”. Tesis, IAIN Sumatera Utara, 2014. Makrum, "Poligami dalam Perspektif Al-Qur'an", Disampaikan Saat Seminar IAIN Purwokerto 28 April 2016. Abd. Moqsith, "Tafsir Atas Poligami dalam Al-Qur'an". Karsa, Vol. 23 No. 1, Juni (2015), h. 133-149. Sam'un, "Poligami Dalam Perspektif Muhammad 'Abduh", AL-HUKAMA The Indonesian Journal of Islamic Family Law, Vol 02, No 01, Juni (2012), h. 102-116.

${ }^{14}$ Muhammad Husain al-Dzahabi, h. 547.

${ }^{15}$ Abdul Mazid Abdussalam al-Mustashib, Visi dan Paradigma Tafsir Alquran Kontemporer, h. 105.

${ }^{16}$ J.J.G. Jansen, Diskursus Tafsir Alquran Modern, trans. oleh Hairussalim (Yogyakarta: Tiara Wacana, 1990), h. 29.

${ }^{17}$ J.J.G. Jansen, Diskursus Tafsir Alquran Modern, trans. oleh Hairussalim (Yogyakarta: Tiara Wacana, 1990), h. 28. 
Tetapi Allah akan menanyakan mengenai kitab-Nya yang diwahyukan untuk membimbing dan mengatur hamba-Nya. ${ }^{18}$

Berangkat dari keprihatinan itu Muhammad 'Abduh mencoba menyederhanakan metode penafsiran Alquran dengan meninggalkan pembahasan yang bertele-tele dari segi nahwu-sharaf dan balâqhah, serta meninggalkan pertentangan-pertentangan pendapat para ulama. Tetapi langsung mengungkapkan kandungan maknanya, tujuan dan hikmahnya, dengan gaya bahasa yang menarik dan pemahaman yang sederhana dan praktis. Sehingga penafsirannya bukan hanya dapat dipahami oleh para ulama, tetapi juga dapat dimengerti oleh kalangan masyarakat umum. ${ }^{19}$

Demikian pembaruan penafsiran Alquran oleh Muhammad 'Abduh yang kemudian banyak diikuti oleh para mufassir sesudahnya. Sehingga menurut 'Abdussalâm al-Mutasib, Muhammad 'Abduh telah menjadikan tafsir Alquran sebagai pijakan utama bagi gerakan reformasinya, yaitu dalam membangun masyarakat dan memperbaharui agama. ${ }^{20}$ Lain halnya dengan al-Muhtasib, menurut Harun Nasution bahwa pokok pikiran Muhammad 'Abduh yang menjadi dasar pendapat-pendapatnya dalam pembaruan dalam Islam adalah dalam bidang teologi. ${ }^{21}$ Pemikiran teologi yang dianut oleh Muhammad 'Abduh, demikian menurut hasil peneliltian Harun Nasution, memiliki banyak persamaan pemikiran dengan pemikiran teologi yang dianut kaum Mu'tazilah. Ia memberikan kedudukan yang amat tinggi terhadap teologi kepada akal. Bahkan kekuatan akal dalam pendapat Muhammad 'Abduh, lebih tinggi dari kekuatan akal dalam pemikiran teologi Mu'tazilah. Lain halnya dengan kebebasan berkehendak manusia, sebagaimana paham yang dianut oleh Mu'tazilah, Muhammad 'Abduh menganut paham Qadariah. ${ }^{22}$

Senada dengan hasil penelitian Harun Nasution, Sulaiman Dunya menilai pemikiran Muhammad 'Abduh dalam memberi kedudukan kepada

${ }^{18}$ Muhammad 'Abduh, Tafsir al-Qur'ân al-Hakìm (Tafsir al-Manâr), 1 (Bayrût: Dâr alFikr, t.t.), h. 26.

${ }^{19}$ J.J.G. Jansen, Diskursus Tafsir Alquran Modern, h. 28-29.

${ }^{20}$ Abdul Mazid Abdussalam al-Mustashib, Visi dan Paradigma Tafsir Alquran Kontemporer, h. 113.

${ }^{21}$ Harun Nasution, Muhammad 'Abduh dan Teologi Rasional Mu'tazilah, h. 1.

${ }^{22}$ Harun Nasution, Muhammad 'Abduh dan Teologi Rasional Mu'tazilah, h. 92-94. 
akal lebih tinggi dari kaum Mu'tazilah. ${ }^{23}$ Demikian pula dengan Usma Amin, ${ }^{24}$ Gardet dan Anawati, ${ }^{25}$ Caspar, ${ }^{26}$ dan Kerr, ${ }^{27}$ mereka sependapat bahwa sebagian pemikiran Muhammad 'Abduh bercorak Mu'tazilah.

Demikian hasil penelitian dalam penelaahan para ahli mengenai pemikiran pembaruan Islam Muhammad 'Abduh dalam bidang teologi. Sebagaimana halnya dalam bidang tafsir, pemikiran pembaruannya dalam bidang ini telah mendapat perhatian yang cukup besar, sehingga telah banyak melahirkan tulisan baik dalam bentuk buku, artikel maupun laporan penelitian, serta berbagai kritik, komentar ataupun ulasan.

Salah satu aspek pemikiran Muhammad 'Abduh yang belum mendapat perhatian para peneliti adalah dalam masalah hukum Islam atau yang lebih dikenal sebagai fiqh. Pemikiran Muhammad 'Abduh dalam bidang fiqh ini nampaknya sangat penting untuk dilakukan penelitian secara seksama, yaitu untuk mengetahui corak pemikiran pembaruannya secara khusus dalam bidang tersebut, serta pengaruhnya terhadap perkembangan dan corak pemikiran pembaruanfigh setelah periode Muhammad 'Abduh.

Muhammad 'Abduh mengatakan, poligami sebagai suatu tindakan yang tidak boleh atau haram. Poligami hanya mungkin bisa dilakukan oleh seorang suami dalam hal-hal tertentu, misalnya ketidakmampuan seorang istri untuk mengandung atau melahirkan. ${ }^{28}$ Setelah mengutip Alquran surat al-Nisẩ ayat 3, ia mencatat Islam memang membolehkan berpoligami, tetapi dituntut dengan syarat keharusan mampu berlaku adil terhadap istri. Dari syarat ini, menurut Muhammad 'Abduh, dapat dirinci menjadi tiga kondisi. ${ }^{29}$

${ }^{23}$ Sulaiman Dunya, ed., al-Syaikh Muhammad Abduh bain al-Falâsifah wa al-Kalâmiyin (Cairo: Isâ al-Bâbî al-Halabî, 1958), Buku Pendahuluan, h. 62.

${ }^{24}$ Usman Amin dan Muhammad 'Abduh, Essai sur ses Ideas Philosofiques et Religieuses (Cairo: Imprimerie Misr SAE, 1994), h. 99.

${ }^{25}$ Gardet dalam Introduction a la Theologie Musulmane (Paris: Librarie Philoshopiques Y. Vrin, 1948), h. 85.

${ }^{26}$ Dalam MIDEO, IV (1957), h. 157, 169, dan 171.

${ }^{27}$ Kerr dalam Islamic Reform, the Political and Legal Theories of Muhammad Abduh amd Rasyîd Ridha (California: University of California Press, 1996), h. 105.

${ }^{28}$ Kerr dalam Islamic Reform, the Political and Legal Theories of Muhammad Abduh amd Rasyîd Ridha, h. 350.

${ }^{29}$ Kerr dalam Islamic Reform, the Political and Legal Theories of Muhammad Abduh amd Rasyîd Ridha, h. 340. 
Pertama, kebolehan berpoligami sesuai dengan kondisi dan tuntutan zaman. Kedua, syarat bisa berbuat adil merupakan syarat yang sangat berat. Sampai-sampai Allah sendiri mengatakan, kalaupun manusia berusaha keras untuk berbuat adil, manusia tidak akan mampu, khususnya dalam hal pembagian cinta dan hal-hal yang berhubungan dengan pelayanan batin. Sementara ada hadis Nabi Saw. yang mengatakan bahwa seorang pria yang mempunyai dua orang istri dan berbuat ketimpangan kepada salah satu diantaranya, di hari kiamat akan merasakan tubuhnya akan rusak. ${ }^{30}$

Ketiga, bahwa seorang suami yang tidak bisa melaksanakan syaratsyarat yang dituntut berpoligami, harusnya melakukan monogami. Setelah menguraikan pentingnya kemampuan bisa berbuat adil, Muhammad 'Abduh kemudian mengatakan, bahwa dengan melihat beratnya syaratsyarat untuk melakukan poligami, maka tujuan utama dari syariat dalam perkawinan adalah monogami. Setelah mengutip Alquran surat al-Nisâ ayat 129, 'Abduh menekankan kemampuan seorang suami melakukan keadilan di antara para istrinya. Dia memang mengakui para sahabat Nabi Saw.melakukan poligami, tetapi hal itu dilakukan karena kondisi yang menghendaki demikian. Karena waktu itu perempuan lebih banyak dari laki-laki. ${ }^{31}$ Karenanya, poligami dilakukan ketika itu untuk tujuan menjaga perempuan. Dalam hal masalah ini, Muhammad 'Abduh sepaham dengan Ameer Ali, yakni kebolehan poligami sangat tergantung kepada situasi dan tuntutan zaman. Karena itu, konteks sejarah ketika turunnya ayat tentang kebolehan poligami harus dibaca secara cermat dan jernih. Dengan kata lain, walaupun Muhammad 'Abduh sangat keras dalam mengharamkan poligami tetapi masih ada kemungkinan untuk melakukannya, yakni manakala ada tuntutan yang benar-benar seseorang melaksanakannya. Larangan atau kebolehan melakukan poligami, bagi Muhammad 'Abduh nampaknya lebih banyak ditentukan oleh tuntutan zaman, yaitu keadaan darurat. Bagi Muhammad 'Abduh, poligami merupakan sesuatu perbuatan

${ }^{30}$ Bunyi hadis tersebut adalah sebagai berikut: Qâla Râsulullah Saw. Man Kânat Lahu Imraatâni Famâlla Ila Ahadihimâ Duna al-Ukhrâ Jâa Yauma al-Qiamâti Mâ Ilun. (H.r. Ahmad Wa al-Arba'ah). Artinya: "seorang pria yang mempunyai dua orang istri dan berbuat ketimpangan kepada salah satu diantaranya, dihari kiamat nanti akan merasakan tubuhnya akan rusak".

${ }^{31}$ Kerr dalam Islamic Reform, the Political and Legal Theories of Muhammad Abduh amd Rasyîd Ridha, h. 353. 
yang haram kalau tujuannya hanya untuk kesenangan. Tetapi jika alas annya dimaksudkan untuk memenuhi kebutuhan biologis kaum Adam, maka hubungannya menjadi tidak boleh. Sebab menurut dia, kalau untuk memenuhi kebutuhan biologis ini, manusia tidak akan pernah puas, dan kalau dituruti terus, manusia tidak ada bedanya dengan binatang. Muhammad 'Abduh juga menyinggung perilaku poligami yang dilakukan sebelum pra Islam, yang menurutnyalebih sering dilakukan sebagai simbol kekuatan atau kejantanan. Latar belakang sejarah inilah barangkali yang membuat Muhammad 'Abduh bersikap sangat ketat terhadap hukum poligami. ${ }^{32}$

\section{Metode Tafsir Kontemporer Muhammad 'Abduh tentang Ayat Poligami}

Kembali kepada pokok pembahasan secara khusus mengenai metode penafsiran Muhammad 'Abduh dalam menafsirkan ayat poligami, yaitu Alquran surat al-Nisầ ayat 3 dan 129. Kiranya sudah jelas bahwa aturan-aturan yang bersifat umum akan meliputi kepada aturan-aturan yang bersifat khusus. Demikian pula metode dan pendekatan yang digunakan Muhammad 'Abduh secara umum dalam tafsir al-Manâr, dengan sendirinya akan dapat dilihat penerapan metode dan pendekatan itu dalam menafsirkan ayat-perayat, termasuk dalam menafsirkan ayat tentang poligami (Alquran surat al-Nisâ ayat 3 dan 129).

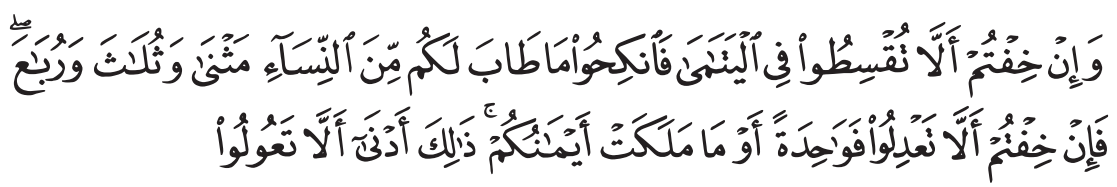

Dan jika kamu takut tidak akan dapat berlaku adil terhadap (hakhak) perempuan yang yatim (bilamana kamu mengawininya), maka kawinilah wanita-wanita (lain) yang kamu senangi yaitu dua, tiga atau empat. Kemudian jika kamu takut tidak akan dapat berlaku adil, maka (kawinilah) seorang saja atau budak-budak yang kamu miliki. Yang demikian itu adalah lebih dekat kepada tidak berbuat aniaya.

${ }^{32}$ Kerr dalam Islamic Reform, the Political and Legal Theories of Muhammad Abduh amd Rasyîd Ridha, h. 264. 


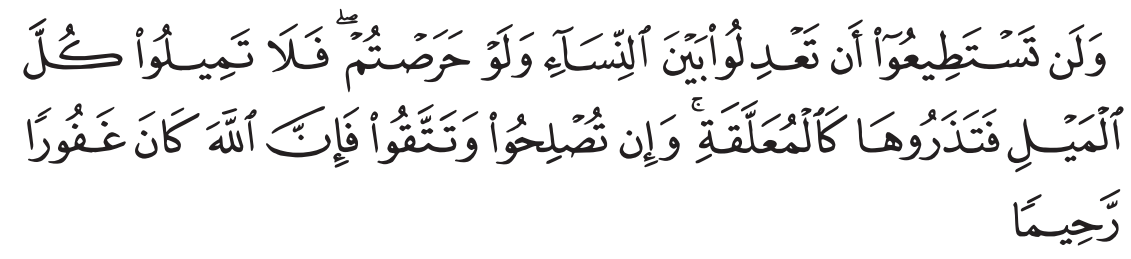

Dan kamu sekali-kali tidak akan dapat berlaku adil di antara isteriisteri (mu), walaupun kamu sangat ingin berbuat demikian, karena itu janganlah kamu terlalu cenderung (kepada yang kamu cintai), sehingga kamu biarkan yang lain terkatung-katung. Dan jika kamu mengadakan perbaikan dan memelihara diri (dari kecurangan), maka sesungguhnya Allah Maha Pengampun lagi Maha Penyayang.

Metode penafsiran yang digunakan Muhammad 'Abduh dalam menafsirkan surat al-Nisầ ayat 3 dan 129 tentang poligami di atas yaitu mengacu kepada metode dan pendekatan penafsiran yang digunakannya secara umum dalam tafsir al-Manâr. Di dalam tafsir al-Manâr, metode untuk menafsirkan ayat di atas,yaitu dengan menggunakan metode tablilly dengan pendekatan bi al-ra'yi. Sedangkan corak dan orientasi penafsirannya, dalam menafsirkan ayat tentang poligami tersebut sebagaimana corak dan orientasi secara umum dalam tafsir al-Manâr adalah orientasi kepada adab al-ijtimầi.

Penafsiran ayat tentang poligami (surat al-Nisầ ayat 3) terdapat dalam tafsir al-Manâr jilid IV, dari halaman 339-375. Pembahasan yang cukup luas, karena ditambah dengan uraian mengenai beberapa hikmah berpoligami, hukum syariat mengenai poligami yang dilakukan Nabi Saw. Namun demikian dalam uraian itu sangat jelas dibedakan, mana yang bersumber dari Muhammad 'Abduh dan mana yang merupakan uraian dari Rasyid Ridha sendiri. ${ }^{33}$

Sebagai pembuka dalam pembahasan, Rasyid Ridha mengemukakan dalam beberapa riwayat yang bersumber dari 'Aisyah, baik yang dinukil dari Shahih Bukhârî dan Muslim, Sunan al-Nasầi, Bayhaqî, maupun yang dinukil dari Tafsir Ibn Jarîr al-Thabani, tentang beberapa kasus yang berhubungan dengan turunnya ayat itu, ataupun tentang materi-materi

${ }^{33}$ A. N. Busool, "Shaykh Muhammad Rashd Ridha Relations With Jamâl-Dâl-Afghni and Muhammad Abduh". The Muslim World, 66 (4), (1976): h. 272-286. 
yang berkaitan dengan masalah poligami. Setelah mengulas riwayat-riwayat tentang kasus yang berkenaan dengan poligami dan mengulas pendapat para ulama terdahulu berkenaan dengan penafsiran ayat tersebut, dengan uraian yang cukup panjang, Rasyid Ridha kemudian mengemukakan penafsiran gurunya, Muhammad 'Abduh, berkenaan dengan ayat tentang poligami tersebut, dalam uraian sekitar tiga halaman.

Uraian berikutnya tentang hikmah berpoligami, hukum syariat tentang berpoligami, dan hikmah berpoligami yang dilakukan oleh Nabi Saw, ini merupakan uraian tambahan dari Rasyid Ridha sendiri. Dengan demikian penafsiran yang disampaikan oleh Muhammad 'Abduh sendiri cukup singkat dan padat, yaitu hanya sekitar 3 (tiga) halaman.

Berbeda dengan metode yang dilakukan oleh Rasyid Ridha, yang memulai pembahasannya dengan menukil beberapa riwayat dan menghadirkan pendapat para mufassir terdahulu, Muhammad 'Abduh mengawali pembahasannya dengan menunjukkan munâsabah isi kandungan ayat itu (al-Nisầ ayat 3) dengan ayat sebelumnya. Dimana keterkaitan antara kedua ayat adalah adil terhadap anak-anak yatim dan larangan memakan harta anak yatim yaitu meskipun melalui hubungan perkawinan. Menurut Muhammad 'Abduh awal ayat ke-3 dari surat al-Nisâ' itu kembali mengingatkan, seandainya merasa khawatir akan memakan harta anak yatim dengan jalan menikahinya, maka hendaklah menikah dengan wanita yang lain saja.

Selanjutnya Muhammad 'Abduh pun menghubungkan surat alNisầ ayat 3 dengan ayat 129. Di dalam Alquran surat al-Nisầ ayat 3 dinyatakan bahwa kebolehan menikah hinggap 4 orang istri itu apabila dapat memenuhi persyaratan mampu berlaku adil, jika tidak makamenurut Muhammad 'Abduh, mesti satu saja. Sedangkan dalam surat yang sama ayat 129 dinyatakan bahwa seorang suami tidak akan mampu berbuat adil terhadap istri-istrinya, meskipun ia sangat menginginkannya. Menurut Muhammad 'Abduh, ketidakmampuan berlaku adil ini adalah ketidakmampuan berlaku adil yang berhubungan dengan kecenderungan hati, sebab jika yang dimaksudkan keadilan secara keseluruhannya (nafkah, kiswah, dan sebagainya), maka penggabungan kedua ayat itu berarti tidak adanya kebolahan berpoligami. Untuk memperkuat pendapatnya 
itu Muhammad 'Abduh mengutip hadits Nabi Saw. yang berisikan do'a penyerahan atas ketidakmampuan Nabi Saw. dalam berbagai keadilan terhadap istrinya, yakni keadilan dalam membagi kecenderungan hati.

Masih menyoroti munâsabah kedua ayat itu (al-Nisẩ ayat 3 dan 129), menurut Muhammad 'Abduh isyarat yang terkandung antara hubungan kedua ayat itu menunjukkan, bahwa poligami merupakan kebolehan yang sempit, sebagai dispensasi bagi orang yang dalam kondisi darurat yang sangat membutuhkannya.

Muhammad 'Abduh kemudian menyoroti kandungan makna ayat itu berdasarkan tinjauan historis dan sosial kontemporer. Menurut analisisnya, bahwa secara historis pada masa awal dalam Islam kebolahan poligami itu merupakan tuntutan kebutuhan masyarakat, dan diakui telah memberikan banyak manfaat, khususnya dalam memperkokoh hubungan nasab dan kekeluargaan, yang dengan cara itu dapat memperkokoh rasa persaudaraan dalam agama (nashabiyah), dan tidak menimbulkan kemadaratan seperti yang terjadi sekarang. Tetapi menurut Muhammad 'Abduh, hal itu bisa terwujud karena ajaran agama telah tertanam kuat dalam jiwa kaum perempuan dan laki-lakinya.

Berdasarkan tinjauan sosial yang berkembang saat sekarang, menurut Muhammad 'Abduh, poligami telah menjadi sumber kemadaratan dan sumber penyakit sosial bagi kalangan orang tua dan anak-anaknya, karena telah menimbulkan beban dan menjadi sumber penyebab timbulnya kriminilatas dan krisis moral, seperti perzinahan, pencurian, khianat, dusta, bahkan pembunuhan sesama anggota keluarga.

Akhirnya Muhammad 'Abduh mengingatkan, bahwa poligami harus dilihat dari segi kemaslahatan dan kemafsadatan dalam pelaksanaannya di masyarakat, dengan alasan bahwa agama (Islam) diturunkan untuk kemaslahatan dan kebaikan umat. Maka berdasarkan tinjauan ini, suatu hukum dapat berubah penerapannya sesuai dengan situasi dan kondisi yang terjadi. Berdasarkan asumsinya itu, dan dihubungkan dengan kaidah ushôl yaitudar'u al-mafâsid muqaddamun 'alâ jalbi al-mashâlih Muhammad 'Abduh berkesimpulan bahwa poligami dapat menjadi haram secara mutlak manakala takut tidak adanya keadilan.

Dari uraian di atas, kiranya cukup jelas bahwa metode penafsiran 
yang digunakan oleh Muhammad 'Abduh dalam menafsirkan ayat tentang poligami, adalah metode tahlily. Sedangkan pendekatan penafsirannya menggunakan pendekatan bi al-rajyi yang berorientasi pada reformasi sosial budaya (adab al-ijtimâì).

Namun demikian kiranya perlu dicatat beberapa kekhususan yang menarik untuk diidentifikasi, sekaligus yang membedakan metode dan pendekatan penafsiran yang digunakan Muhammad 'Abduh dengan yang lainnya. Kekhususan-kekhususan tersebut antara lain:

Pertama, Muhammad 'Abduh meninggalkan tradisi yang biasa ditemukan dalam tafsir metode tahlily yang lain, yaitu berlarut-larut dalam memperdebatkan tinjauan lafazh matsnâ wa tsulâtsa wa rubâ',Muhammad 'Abduh memandang bahwa memperdebatkan tinjauan makna lafaz tersebut, merupakan hal yang tidak perlu, karena problem sesungguhnya adalah dalam bagaimana kandungan ayat itu menjadi petunjuk dalam menegakkan keadilan dan kemaslahatan di tengah-tengah masyarakat.

Kedua, Muhammad 'Abduh juga tidak banyak mengutip hadis-hadis dari sumber-sumber periwayatan lainnya, yang biasa yang dijadikan sumber atau dasar penafsiran oleh mufassir-mufassir sebelumnya. Sebab, mungkin riwayat-riwayat itu hanya memberikan informasi tentang pembatasan jumlah wanita yang boleh dimadu dalam berpoligami, dimana hal itu dipandang sebagai hal yang sudah mafhum, sebagaimana yang tersurat dalam ayat itu sendiri (al-Nisâ’: 3).

Ketiga, demikian juga, Muhammad 'Abduh tidak mengangkat dan tidak merujuk kepada pendapat-pendapat para mufassir terdahulu, dalam menafsirkan ayat tersebut. Barangkali hal tersebut disebabkan di samping pendapat-pendapat para mufassir itu tidak sejalan dengan pandangannya, juga seperti yang dikatakan oleh banyak pengamat bahwa Muhammad 'Abduh berusaha menghindari perdebatan yang tidak perlu, dan sebaliknya ia menafsirkan Alquran dengan ijtihadnya sendiri tanpa terikat oleh pendapat para ulama sebelumnya.

Keempat, Muhammad 'Abduh menganalisis persoalan poligami berdasarkan tinjauan sosio-historis dan sosial kontemporer. Hal ini merupakan metode baru yang tidak dilakukan oleh mufassir sebelumnya. Dengan cara ini Muhammad 'Abduh ingin menunjukan bahwa aturan poligami 
bukan sekedar ideal normatif tetapi dalam aplikasinya justeru poligami barus dilihat sebagai kondisonal normatif. Hal ini kerena menurut Muhammad 'Abduh bahwa inti dari suatu ajaran hukum adalah keadilan dan kemaslahatan, jika suatu aturan hukum pada masa tertentu tidak membawa kemaslahatan dan keadilan, maka harus dicari alternatif lain yang bisa membawa keadilan dan kemaslahatan.

\section{Hukum Poligami Menurut Muhammad 'Abduh}

Muhammad 'Abduh tidak menolak bahwa pada awal Islam aturan mengenai poligami dapat dipandang sebagai solusi terbaik dari problem-problem sosial yang dihadapi masyarakat pada saat itu, sehingga kebolehan berpoligami telah memberikan banyak manfaat. Manfaat yang tepenting dari poligami pada awal Islam adalah menjalin hubungan nasab dan kekeluargaan, sehingga dengan cara itu akan dapat membangun kekuatan 'ahabi'ah (kekuatan persaudaraan Islam). Selain itu menurut Muhammad 'Abduh, pelaksanaan poligami di masa Rasulullah Saw. dan sahabat didasarkan pada keyakinan agama yang kuat yang telah bersemayam dalam jiwa kaum perempuan dan laki-lakinya, sehingga mereka melaksanakannya berdasarkan tuntutan syariat bukan keinginan hawa nafsu, dan karenanya tidak menimbulkan kemadaratan sebagaimana yang disaksikan pada sekarang. ${ }^{34}$

Pandangan Muhammad 'Abduh mengenai poligami di masa awal Islamnampaknya senada dengan pandangan para mufassir pada umumnya yang menyatakan bahwa kondisi saat itu memang menghendaki poligami menjadi solusi dan problem sosial yang dihadapi. Problem yang terpenting adalah banyaknya anak-anak yatim dan janda-janda yang ditinggal mati oleh bapak atau suaminya di medan perang, mereka tentu saja amat memerlukan perlindungan dan tuntunan baik materil maupun nonmarteril. Dengan adanya kebolehan poligami yang dilandasi oleh syarat berlaku adil dan tidak aniaya, maka beban sosial semacam itu dapat teratasi.

${ }^{34}$ Muhammad Abduh, Ilmu dan Peradaban menurut Islam dan Kristen, trans. oleh Mahyudin Syafdan Bakar Usman (Bandung: Diponegoro, 1978), h. 92. 
Selain itu, seperti dikemukakan oleh Ibn Jarir al-Thabari dan banyak mufassir lain, bahwa aturan poligami dalam syariat Islam sebenarnya adalah untuk membatasi jumlah istri dan memperlakukan mereka secara adil, karena dalam tradisi masyarakat Arab sebelumnya kebiasaan berpoligami telah dilakukan dengan tanpa batas dan tanpa memperhatikan keadilan bagi kaum perempuan. ${ }^{35} \mathrm{Namun}$ demikian dalam pandangan Muhammad 'Abduh kebolehan berpoligami bukanlah aturan hukum yang tetap dan baku. Aturan tersebut tetap harus dilihat dari segi kemaslahatan dan kemadaratannya dalam pelaksanaan di masyarakat, sehingga jika ia ternyata membawa dampak negatif pada suatu masa, yang sebelumnya tidak pernah ditemukan, maka tidak ragu lagi aturan itu harus dirubah dalam pelaksanaannya sesuai dengan situasi dan kondisi yang berkembang. Hal ini sesuai dengan kaidah: Dar-u al-mafâsid muqaddamun 'alâ jalbi al-mashâlih (mencegah kemafasadatan harus lebih diutamakan ketimbang mengusahakan kemaslahatan). ${ }^{36}$

Pandangan Muhammad 'Abduh ini telah mendobrak paradigma penafsiran sebelumnya, yang terikat secara ketat terhadap teks ayat, tanpa memberikan ruang pertimbangan terhadap pemahaman teks ayat tersebut yang dihubungkan dengan konteks sosial dan dinamika perubahan jaman. Paradigma penafsiran sebelumnya, yang memandang kebolehan berpoligami sebagai aturan normatif yang bersifat tetap, dengan demikian tidak bisa dipertahankan lagi, karena menurut penelitian Muhammad 'Abduh, penafsiran semacam itu dalam kenyataan sejarah berikutnya telah menimbulkan banyak anomali-anomali.

Anomali-anomali yang muncul antara lain, yaitu: Pertama, dari segi pemahaman teks ayat itu sendiri, di mana bila dihubungkan antara surat al-Nisầ ayat 3 yang memberi isyarat kebolehan berpoligami, dengan alNisầ ayat 129 yang menyatakan ketadikmampuan seorang suami belaku adil, maka pesan yang sesungguhnya ingin disampaikan oleh Alquran adalah bukan tentang kebolehan berpoligami sebagai aturan yang berlaku

${ }^{35}$ Muhammad Rasyid Ridha, Tarîkh al-Ustâdz al-Imâm Muhammad 'Abduh (Kairo: Dâr al-Manâr, 1931), h. 344-345.

${ }^{36}$ Muhammad 'Abduh, Tafsir al-Qur'ân al-Hakìm (Tafsir al-Manâr), 350.dan Abdul Mazid Abdussalam al-Mustashib, Visi dan Paradigma Tafsir Alquran Kontemporer, h. 192. 
umum, melainkan bahwa poligami itu merupakan kebolehan yang bersifat terbatas (sempit) bahkan sangat terbatas, yaitu kebolehan yang diberikan ketika dalam kondisi yang sangat terpaksa (dlarûrah) bagi orang yang secara alasan hukum sangat membutuhkannya, itupun dengan persyaratan yang berat yaitu harus mampu berlaku adil dan terjamin untuk tidak berbuat aniaya. ${ }^{37}$

Kedua, dalam pelaksanaanya di masyarakat poligami seringkali tidak ditegakkan dengan keadilan, karena itu poligami dapat menimbulkan kezaliman, ketidakpatuhan terhadap aturan dan hilangnya keharmonisan, sehingga tidak mungkin dapat menegakkan kebahagiaan dalam keluarga sebagaimana yang menjadi tujuan dari sebuah perkawinan. Terjadi justeru sebaliknya, suami istri masing-masing berusaha saling menghancurkan rumah tangganya. Sehingga pada gilirannya kerusakan-kerusakan semacam itu dapat menyebar dari individu ke keluarga dan keluarga ke masyarakat. ${ }^{38}$

Ketiga, kebolehan berpoligami seringkali digunakan alasan oleh suami untuk menuruti keinginan-keinginan nafsu biologis, padahal keinginankeinginan itu tidak akan pernah puas, justeru hal inilah sesungguhnya yang berjalan di kalangan masyarakat Arab Jahiliyah dan Islam datang untuk mencegah. ${ }^{39}$

Anomali-anomali itu kian lama kian memuncak, serhingga pada gilirannya telah menimbulkan krisis dan penyakit sosial yang amat parah di kalangan masyarakat luas, khususnya yang disaksikan oleh Muhammad 'Abduh sendiri di Mesir. Menurut Muhammad 'Abduh, dampak dari poligami benar-benar telah mengkhawartirkan, ia telah menimbulkan dendam dan permusuhan di antara keluarga, antara anak dengan orang tua, dan antara sesama saudara, dan pada gilirannya menimbulkan malapetaka dan kerusakan moral bagi umat secara keseluruhan.

“... Jika orang mau merinci kejelekan-kejelekan dan berbagai musibah yang menjadi dampak poligami,maka sudah tentu anda akan melihat tubuh orang mukmin menjadi gemetar. Antara lain kejelekan dan musibah itu adalah pencuri, perzinahan, dusta, khianat, pengecut, berdusta bahkan

\footnotetext{
${ }^{37}$ Muhammad 'Abduh, Tafsir al-Qur'ân al-Hakìm (Tafsir al-Manâr), h. 349.

${ }^{38}$ Muhammad 'Abduh, Tafsir al-Qur'ân al-Hakim (Tafsir al-Manâr), h. 350.

${ }^{39}$ Muhammad 'Abduh, Tafsir al-Qur'ân al-Hakim (Tafsir al-Manâr), h. 192.
} 
termasuk pembunuhan, hingga anak membunuh orang tuanya, orang tua membunuh anaknya. Semuanya itu adalah fakta yang terjadi saat ini dipengadilan-pengadilan. Jika permasalahannya seperti yang kita saksikan dan kita dengarkan, maka tentu tidak ada jalan untuk membina umat karena berkembangnya poligami di tengah-tengah mereka. Sehingga para ulama harus benar-benar memperhatikan masalah ini....". ${ }^{40}$

Dengan demikian Muhammad 'Abduh mengkritik penafsiran yang memperbolehkan poligami secara longgar, di mana penafsiran mereka hanya didasarkan pada kajian-kajian tekstual dan argumen-argumen kebahasaan semata, tanpa menghubungkan ideal moral yang terkandung dalam aya-ayat Alquran itu dengan misi sosialnya. Sehingga keberadaan tafsir Alquran seolah-olah hanya untuk dunianya sendiri dan tidak memperhatikan realitas yang terjadi dalam kehidupan sosial.

Padahal menurut Muhammad 'Abduh, mereka (para ulama) tidak memungkiri bahwa sesungguhnya Islam diturunkan untuk kemaslahatan dan kebajikan manusia, dan bahwa sesungguhnya di antara landasan pokok dan agama ini adalah menghilangkan kemudaratan-kemudaratan. Oleh krena itu, mestinya jika suatu aturan hukum telah menimbulkan kemafsadatan pada suatu masa yang sebelumnya tidak pemah ditemukan, maka tidak ragu lagi aturan hukum itu harus dirubah dan dalam penerapannya harus disesuaikan dengan kebutuhan akan kemaslahatan yang terjadi pada saat sekarang. Hal ini sesuai dengan kaidah dar-u almafâsid muqaddamun 'alâ jalbi al-mashâlih... ${ }^{41}$

Bertolak dari landasan pemikiran itu, dan dihubungkan dengan penafsiran terhadap surat al-Nisầ ayat 3 dan 129, Muhammad 'Abduh berkesimpulan bahwa, kebolehan berpoligami dalam Islam merupakan aturan yang bersifat sangat terbatas. Seakan-akan ia merupakan jalan keluar yang bersifat darurat ketika menghadapi kemadaratan yang lebih besar, bagi orang yang sangat membutuhkanya dengan syarat mampu menegakkan keadilan dan menjamin untuk tidak berlaku aniaya. ${ }^{42}$ Bahkan, menurut Muhammad 'Abduh, poligami dapat menjadi haram

${ }^{40}$ Muhammad 'Abduh, Tafsir al-Qur'ân al-Hakìm (Tafsir al-Manâr), h. 394.

${ }^{41}$ Muhammad 'Abduh,Tafsir al-Qur'ân al-Hakìm (Tafsir al-Manâr), h. 350 dan Abdul Mazid Abdussalam al-Mustashib, Visi dan Paradigma Tafsir Alquran Kontemporer, h. 192.

${ }^{42}$ Muhammad 'Abduh, Tafsir al-Qur'ân al-Hakìm (Tafirir al-Manâr), h. 349. 
secara mutlak, bagi orang yang takut tidak bisa berlaku adil. ${ }^{43}$

Berdasarkan teori paradigma Thomas S. Kuhn, paradigma penafsiran Muhammad 'Abduh tentang poligami ini dapat dipandang sebagai paradigma penafsiran baru, hasil sebuah revolusi dari paradigma penafsiran sebelumnya, yang telah memunculkan anomali-anomali dan terbukti telah menimbulkan krisis sosial dan krisis moral di kalangan umat. Paradigma penafsiran baru ini diharapkan dapat menjadi solusi alternatif untuk menghilangkan anomali-anomali yang ada, sekaligus dapat membawa umat keluar dari krisis yang telah dihadapinya.

Adapun mengenai paradigma penafsiran Muhammad 'Abduh berdasarkan skema di atas dapat dirumuskan sebagi berikut: Pertama, kebolehan berpoligami dalam Islam bukanlah merupakan hukum yang pokok melainkan sebagai alternatif jalan keluar ketika dalam situasi darurat yang bersifat terbatas. Kebolehan ini pun harus disertai dengan syarat mampu berlaku adil dan menjamin untuk tidak berbuat aniaya. Kedua, aturan hukum berpoligami ini merupakan aturan hukum yang bersifat kondisional, tergantung kepada situasi dan kondisi serta maslahat dan mafsadatnya bagi kepentingan umat. Dengan kata lain, pada saat tertentu poligami dapat dibolehkan karena kemaslahatan umat menghendaki demikian, dan pada saat yang lain menjadi haram apabila menimbulkan kemadaratan yang meluas di kalangan umat. Ketiga, paradigma penafsiran ini didasarkan pada pesan yang terkandung dalam Alquran surat alNisâ' [4] ayat 3, intinya selain membatasi jumlah kebolehan bepoligami, juga memberikan persyaratan bagi orang yang hendak melakukannya. Seperti halnya dengan keharusan berlaku adil dan terjamin untuk tidak berbuat aniaya. Kandungan ayat tersebut dihubungkan dengan surat alNisâ’[4] ayat 129, yang menyatakan ketidakmungkinan seorang suami berbuat adil meskipun sangat menginginkannya. Selain itu juga didasarkan pada pertimbangan kemaslahatan dan kemafsadatan dalam pelaksanaan bagi kepentingan umat; dan Keempat, paradigma penafsiran ini lebih berorientasi kepada kemaslahatan dan pembinaan masyarakat (al-ijtimâii).

${ }^{43}$ Muhammad 'Abduh, Tafsir al-Qur'ân al-Hakim (Tafsir al-Manâr), h. 350. 


\section{Skema: Paradigma Penafsiran Muhammad 'Abduh Tentang Poligami}

\begin{tabular}{|c|c|c|c|c|}
\hline $\begin{array}{c}\text { Paradigma } \\
\text { Penafsiran Lama }\end{array}$ & $\begin{array}{l}\text { Anomali- } \\
\text { anomali }\end{array}$ & $\begin{array}{c}\text { Krisis Paradigma } \\
\text { Lama }\end{array}$ & Reformasi & $\begin{array}{c}\text { Paradigma } \\
\text { Penafsiran Baru }\end{array}$ \\
\hline $\begin{array}{l}\text { 1. Pembatasan } \\
\text { poligini } \\
\text { maksimum } \\
\text { 4/9/19 orang; } \\
\text { 2. Kebolehan } \\
\text { poligini } \\
\text { merupakan } \\
\text { hukum asal; } \\
\text { 3. Dasar-dasar } \\
\text { penafsiran: } \\
\text { a. Teks ayat surat } \\
\text { al-Nisâ [4] ayat } \\
\text { 3; } \\
\text { b. Hadits-hadits } \\
\text { Nabi Saw; } \\
\text { c. Pengalaman } \\
\text { sahabat; } \\
\text { d. Analisis lafaz } \\
\text { atau pendekatan } \\
\text { lughawi } \\
\text { (kebahasaan). }\end{array}$ & $\begin{array}{l}\text { 1. Keadilan } \\
\text { merupakan } \\
\text { hal yang } \\
\text { tidak } \\
\text { mungkin } \\
\text { dilakukan; } \\
\text { 2. Tidak ada } \\
\text { keharmonisan } \\
\text { dalam } \\
\text { keluarga; } \\
\text { 3. Kerusakan } \\
\text { keluarga dan } \\
\text { moral; dan } \\
\text { 4. Poligini } \\
\text { menjadi } \\
\text { alasan untuk } \\
\text { mengikuti } \\
\text { keinginan } \\
\text { nafsu } \\
\text { syahwat. }\end{array}$ & $\begin{array}{l}\text { 1. Poligini } \\
\text { menimbulkan } \\
\text { dendam dan } \\
\text { permusuhan } \\
\text { dalam } \\
\text { keluarga; } \\
\text { 2. Kerusakan } \\
\text { moral di } \\
\text { masyarakat; } \\
\text { dan } \\
\text { 3. Kriminalitas } \\
\text { hingga pada } \\
\text { ketingkat } \\
\text { pembunuhan } \\
\text { orang tua, } \\
\text { anak, suami } \\
\text { maupun istri. }\end{array}$ & $\begin{array}{l}\text { 1. Merubah } \\
\text { paradigma } \\
\text { lama dengan } \\
\text { paradigma } \\
\text { yang baru } \\
\text { dengan } \\
\text { kriteria: } \\
\text { a. Dapat } \\
\text { menjawab } \\
\text { problematika } \\
\text { yang ada; } \\
\text { b. Dapat } \\
\text { memberikan } \\
\text { solusi; } \\
\text { c. Dapat } \\
\text { membawa } \\
\text { keluar dari } \\
\text { krisis yang } \\
\text { dihadapi } \\
\text { masyarakat; } \\
\text { dan } \\
\text { d. Bersikap kritis } \\
\text { dan radikal } \\
\text { terhadap } \\
\text { paradigma } \\
\text { lama. }\end{array}$ & $\begin{array}{l}\text { 1. Kebolehan } \\
\text { poligini } \\
\text { bukan hukum } \\
\text { asal, tetapi } \\
\text { merupakan } \\
\text { dispensasi dalam } \\
\text { kondisi darurat, } \\
\text { bersifat terbatas, } \\
\text { dengan syarat } \\
\text { mutlak adil dan } \\
\text { tidak aniaya; } \\
\text { 2. Aturan hukum } \\
\text { poligini bersifat } \\
\text { kondisional } \\
\text { sehingga } \\
\text { pelaksanaannya } \\
\text { berdasarkan } \\
\text { pertimbangan } \\
\text { kemaslahatan } \\
\text { dan } \\
\text { kemafsadatan. } \\
\text { Oleh karena } \\
\text { itu, pada } \\
\text { kondisi tertentu } \\
\text { bisa menjadi } \\
\text { haram. Dasar } \\
\text { penafsirannya } \\
\text { yaitu: } \\
\text { a. Alquran surat } \\
\text { al-Nisâ ayat } 3 \\
\text { dihubungan } \\
\text { dengan al-Nisâ } \\
\text { ayat 129; } \\
\text { b. Al-Mashlahah } \\
\text { al-Mursalah } \\
\text { dan Sadd al- } \\
\text { Dzariah; dan } \\
\text { c. Orientasi } \\
\text { penafsiran. }\end{array}$ \\
\hline
\end{tabular}




\section{Penutup}

Berdasarkan pemaparan di atas, dapat disimpulkan ke dalam tiga uraian sebagai berikut: Pertama, paradigma Muhammad 'Abduh tentang poligami merupakan antitesa dari paradigma penafsiran sebelumnya. Menurutnya poligami dipandang sebagai solusi terbaik dari problem-problem sosial yang dihadapi masyarakat pada saat itu, sehingga kebolehan berpoligami telah memberikan banyak manfaat, seperti menjalin hubungan nasab dan kekeluargaan. Kedua, metode Mubammad 'Abduh dalam menafsirkan ayat Alquran tentang poligami, yaitu menafsirkan ayat dengan ayat yang lainnya, karena antara ayat yang satu dengan ayat yang lainnya merupakan satu kesatuan, menafsirkan ayat Alquran hanya dengan hadis-hadis yang sahih, menguraikan kalimat demi kalimat secara sempurna, menjelaskan kandungan maknanya, maksud-maksud dan hikmah-hikmah yang terkandung di dalamnya serta membandingkan dengan para mufassirin sebelumnya. Pendekatan yang dipakai Muhammad 'Abduh dalam penafsirannya dapat dikategorikan sebagai jenis penafsiran bi al-rajyi.

Ketiga, faktor-faktor yang sangat dominan berpengaruh terhadap karakteristik pemikiran dan pola penafsiran Muhammad 'Abduh antara lain, yaitu latar belakang pendidikan atau keilmuan, latar belakang sosial, dan latar belakang kultur yang dihadapi pada saat dia masih hidup. Menurutnya poligami merupakan salah satu faktor penyebab terjadinya krisis sosial dan krisis moral di kalangan umat Islam. Terjadinya poligami yang telah meluas dikalangan berbagai lapisan masyarakat dan mendapat legitimasi dari para fukaha, telah menjadi faktor penyebab timbulnya dendam dan permusuhan diantara anggota keluarga serta menyebabkan timbulnya kriminalitas di kalangan masyarakat luas.Berdasarkan pertimbangan tersebut, Muhammad 'Abduh sampai pada kesimpulan bahwa poligami bisa menjadi haram, ketika takut hilangnya keadilan.

\section{Pustaka Acuan}

'Abduh, Muhammad. Tafsir al-Qur'ân al-Hakîm (Tafsir al-Manâr), 1. Bayrût: Dâr al-Fikr, t.t.

Abbas, Nurlaelah. "Muhammad Abduh: Konsep Rasionalisme dalam Islam." Jurnal Dakwah Tabligh 15, no. 1 (2014): 51-68. 
Amin, Usman dan Muhammad 'Abduh. Essai sur ses Ideas Philosofiques et Religieuses. Cairo: Imprimerie Misr SAE, 1994.

Amir, A. N., Shuriye, A. O., \& Ismail, A. F. "Muhammad Abduh's Contributions to Modernity". Asian Journal Of Management Sciences And Education ISSN. (2012).

Ayuni, Dea. "Analisis Pemikiran Ali Abdur Raziq Tentang Negara dalam Perspektif Islam.” PhD diss., Universitas Islam Negeri "Sultan Maulana Hasanuddin” Banten, 2018.

Bahri, Syaiful. "Kontribusi Pemikiran Qasim Amin dalam Pembaruan Hukum Keluarga Islam.” Al-Ahwal: Jurnal Hukum Keluarga Islam 6, no. 1 (2016): 15-28.

Busool, A. N. "Shaykh Muhammad Rashd Ridha Relations With JamâlDâl-Afghni and Muhâmmad Abduh". The Muslim World, 66 (4), (1976): 272-286.

Bluhm, Jutta E. "A Preliminary Statement on the Dialogue Established Between the Reform Magazine al-Manar and the Malayo-Indonesian World." Indonesia Circle, 11, no. 32 (1983): 35-42.

Dzahabi, Muhammad Husain al-. al-Tafsîr wa al-Mufasirûn, II. Cairo: Dâr al-Kutub al-Haditsah, 1976.

Dunya, Sulaiman ed., al-Syaikh Muhammad Abduh bain al-Falâsifah wa al-Kalâmiyin. Cairo: Isâ al-Bâbî al-Halabî, 1958.

Escovitz, J. H. "He was the Muhammad'Abduh of Syria: A Study of Tâhir Al-Jazâiirî and His Influence”. International Journal of Middle East Studies, 18 (3), (1986): 293-310.

Fuadi, Muhammad Ali. "Ayat-ayat Pertanian dalam Al-Qur'an (Studi Analisis Terhadap Penafsiran Thanthawi Jauhari dalam Kitab al-Jawâhir fî Tafsîr al-Qur’an al-Karîm).” PhD diss., UIN Walisongo, 2016.

Gardet dalam Introduction a la Theologie Musulmane. Paris: Librarie Philoshopiques Y. Vrin, 1948.

Gusmawati, Yuli. "Makna Kata Ma'ruf Dan Padanannya dalam al-Qur'an (Suatu Kajian Terhadap Penafsiran Al-Maraghi).” PhD diss., Universitas Islam Negeri Sultan Syarif Kasim Riau, 2011. 
Hidayat, Asep Ramdan. "Islam dan Negara Pemikiran Ali Abd. ArRaziq." Mimbar: Jurnal Sosial dan Pembangunan 19, no. 2 (2003): 159-168.

Human, Fajar Islami. "Makna Kata Adna dan Khayr dalam Surat al-Baqarah ayat 61 menurut Tantawi Jauhari dan Fakhr al-Din al-Razy." PhD diss., UIN Sunan Ampel Surabaya, 2018.

Ismail, Muhamad Fadlly, Nor Hafizi Yusof, and Wan Ruswani Wan Abdullah. "Metodologi dan Pemikiran Syaykh Mustafa Abdul Rahman: Kajian Terhadap Tafsir Al-Quran Al-Hakim Juzu' Satu.” Journal of Maalim al-Quran wa al-Sunnah 12, no. 13 (2017): 100-118.

Jansen, J.J.G. Diskursus Tafsir Alquran Modern, trans. oleh Hairussalim (Yogyakarta: Tiara Wacana, 1990), 29.

Jung, Dietrich. "Islamic Reform and the Global Public Sphere Muhammad Abduh and Islamic Modernity." The Middle East and Globalization Encounters and Horizons. Stephan Stetter (Eds.). New York: Palgrave MacMillan (2012).

Kuntowijoyo. Paradigma Islam Interpretasi untuk Aksi. Bandung: Alfabeta, 1991.

Kerr dalam Muhammad Abduh, Ilmu dan Peradaban menurut Islam dan Kristen, trans. oleh Mahyudin Syafdan Bakar Usman. Bandung: Diponegoro, 1978.

Loeis, Wisnawati. "Nilai-nilai Pendidikan Islam dalam Tafsir Ahmad Musthafa Al-Maraghi: Studi Analisis terhadap Al-Qur'an Surat Al-Fiil.” Turats (Jurnal Pemikiran dan Peradaban Islam) 7, no. 1 (2011): 74-87.

Makrum, "Poligami dalam Perspektif Al-Qur'an", Disampaikan Saat Seminar IAIN Purwokerto 28 April 2016.

Masnur. "Al-Maraghi (Pemikiran Teologinya)." Anida' 36, no. 2 (2011): 260-270. Rosyanti, Imas. "Penggunaan Hadis dalam Tafsir AlMaraghi." Diroyah: Jurnal Studi Ilmu Hadis 2, no. 2 (2018): 137-146.

Mustashib, Abdul Mazid Abdussalam al-. Visi dan Paradigma Tafsir Alquran Kontemporer, trans. oleh M. Maghfur W Bangil: al-'Izzah, 1997.

Moqsith, Abd. "Tafsir Atas Poligami dalam Al-Qur'an”. Karsa, Vol. 23 No. 1, Juni (2015): 133-149. 
Makrum, M. "Teologi Rasional: Telaah atas Pemikiran Kalam Muhammad Abduh." Ulumuna 13, no. 2 (2009): 277-304.

Nasution, Narun. Muhammad Abduh dan Teologi Rasional Mu'tazilah. Jakarta: UI-Press, 1987.

Nabeel, A. Khoury, and Abdo I. Baaklini. "Muhammad 'Abduh: An Ideology of Development." The Muslim World 69, no. 1 (1979): 42-52.

Nurdin, Ahmad Ali. "Islam and State: A Study of the Liberal Islamic Network in Indonesia, 1999-2004." New Zealand Journal of Asian Studies 7, no. 2 (2005): 20.

Prawoto, Agung. "Studi Kritis Pemikiran Politik Ali Abdul Raziq." KALIMAH 16, no. 1 (2018): 1-22.

Rangkuti, Ahmad Zuhri. "Studi Analisis Konsep Muhammad 'Abduh (1266-1323 H/1849-1905) Tentang Al-Qawwâmah dan Implikasinya Terhadap Kedudukan Perempuan dalam Hukum Islam”. Tesis, IAIN Sumatera Utara, 2014.

Ridha, Muhammad Rasyid. Tarîkh al-Ustâdz al-Imâm Muhammad 'Abduh. Kairo: Dâr al-Manâr, 1931.

Rosyanti, Imas. "Penggunaan Hadis dalam Tafsir Al-Maraghi." Diroyah: Jurnal Studi Ilmu Hadis 2, no. 2 (2018): 137-146.

Sam'un. "Poligami dalam Perspektif Muhammad 'Abduh". AL-HUKAMA The Indonesian Journal of Islamic Family Law. Vol 02, No 01, Juni (2012): 102-116.

Scharbrodt, O. "The Salafiyya and Sufism: Muhammad 'Abduh and His Risâlat al-Wâridât (Treatise on Mystical Inspirations)". Bulletin of the School of Oriental and African Studies, 70 (1), (2007): 89-115.

Syamsi, Badarus. "Pemikiran Ali Abdurraziq Tentang Hubungan Islam dan Negara.” TAJDID: Jurnal Ilmu Ushuluddin 14, no. 2 (2015): 325-342.

Vatikiotis, Panayiotis Jerasimof. "Muhammad 'Abduh and the Quest for a Muslim Humanism." Arabica (1957): 55-72.

Wijaya, Aksin. "Kritik Nalar Tafsir Syi'ri." Millah: Jurnal Studi Agama 10, no. 1 (2010): 1-24. 